\title{
A Study of Community and Regional Potential Tende Village, Bentian Besar District, West Kutai Regency, East Kalimantan Province
}

\author{
Abd. Rachim AF, Muhammad Habibi \\ \{rachim_54@yahoo.co.id ${ }^{1}$, rindming@gmail.com ${ }^{2}$ \} \\ ${ }^{1,2}$ University of Widya Gama Mahakam, J1. K. H. Wahid Hasyim No. 28 Samarinda, East Borneo
}

\begin{abstract}
Tende Village was designated as a Pilot Village by the National Development Planning Board of the Republic of Indonesia in East Kalimantan which was also included in the $3 \mathrm{~T}$ area category along with 3 (three) neighboring villages namely Sambung, Randa Empas, and Tukuq villages which were also in a border area on the Trans Kalimantan route East and Central Kalimantan. As villages in general, of course this village has the potential that must be explored and developed, both the potential of the community and the potential of the Tende Village area, as well as the right development model to be applied. This study uses 2 (two) analytical tools namely LQ and interactive analysis of Miles and Huberman. The results of this study were (1) the Potential of the Tende Village Community was in the form of farming skills in the fields, having future human resources, and the culture of the Dayak Bentian Tribe. (2) Potential of Tende Village Area includes as gross as Agriculture, other SDAs such as Forests that produce Ulin, Natural Honey, Rattan, Other Timber, Education sector, Rattan Craft industry sector, Artificial Swallow Nest, Tourism sector in the form of Rattan craft workshop and Bentian Besar culture, as well as the Health sector as a border health center. (3) The development model of the potential of the Tende Village community and region makes it possible to apply (a) models that are research stations and ecological tourism and (b) agropolitan area models in accordance with the characteristics and local wisdom of Tende Village.
\end{abstract}

Keywords: potential, community, region, Tende Village, Dayak Bentian Kutai Barat.

\section{Introduction}

Community development as a whole (comprehensive) or commonly known as Social Development becomes very important when talking about equality, empowerment and independence of development, especially about people who are in the deepest rural areas and are located in border regions between provinces, especially in areas that are Underdeveloped, Outermost, and Leading (3T) But it is not an easy matter when the development is in touch with the values that are believed by the community, such as norms, customs, beliefs, togetherness, politeness and so forth[1].

The complexity of social development must be considered in detail so that the development methods and models can be appropriate to the needs and characteristics of the local community[2]. For this reason, it is necessary to study the potential of the community and the area in the village which will be intervened through a participatory approach[3]. 
Although empowerment aims to improve welfare, especially in the social and economic fields, in some cases there is a resistance from the local community because the pattern of empowerment is considered to violate the values and local wisdom they believe in[4]. As an effort to foster community participation in the development of the empowerment of a community, a participatory approach is needed. So that each program is designed in accordance with the needs of the community, not the desire of the Agent of Change[5].

Therefore, a study of the potential of the community and the occupied territories is needed, so that the development will be very environmentally friendly. Through the potential review process, it is hoped that the agents of change will not go wrong when they have to come into contact with people who are very sensitive to change, especially when the agents of change come from outside their social structure[6].

Indeed, there are some cases where people want the industries to enter their regions with hope that they will be able to take part in the industry[7]. But are they ready with a number of competency requirements desired by the industry, or the community will only become spectators and become the object of the pollution impacts and other effects of industrialization produced by the industry, not to mention when many newcomers with different backgrounds, cultures and beliefs[8][9].

This problem must be a concern of the community, agent of change and local government so that if there is an industry and open access, the community is ready with competencies based on local wisdom and principled on independence and empowerment that are prosperous[10]. The Republic of Indonesia Ministry of Research, Technology and Higher Education, through the Director of Research and Community Service number E3.3 / PM / 2017 in March 2017, has appointed Tende Village, Bentian Besar District, West Kutai Regency as a priority village for programs or activities in the Real Work College (KKN) for universities in East Kalimantan Province.

The University of Widya Gama Mahakam (UWGM) Samarinda has carried out Thematic KKN in Tende Village ON August 2017 for the first time, so the research team intends to strengthen the results of the Thematic KKN, and become a preliminary study for submission of grants offered by the ministry in 2018 .

\section{Method}

Referring to the research problems and research objectives that will provide understanding and describe the potential of the people and the potential of rural areas in Tende Village, Bentian Besar District, West Kutai Regency, this study used the Mix Method approach, with qualitative and descriptive combination[11][12][13].

Location Quotient (LQ) Theory, According to Wiwaha (2013) that "The LQ method is a method that compares the portion of employment/amount of production/added value for a particular sector in a region compared to the portion of employment/total production/added value for the same sector nationally. The purpose of this LQ method is to identify the leading sectors (bases) in a region. The location quotient (LQ) analysis technique is a beginning way to determine the ability of an area in a particular activity sector. This method has not given a final conclusion. The conclusions obtained are only a temporary conclusions that still need to be reviewed through other analytical techniques that can answer whether the conclusions above can prove the truth. 


\section{Findings and Discussions}

Based on the results of the BPS Documents, Community and Area Observations, and also Interviews with the informants, it can be obtained a number of information about the potential of the people and the area of Tende Village areas, as the results of the interview, matrix are attached.

Following in Chapter 4, Research Analysis there are 3 (three) analysis tools used, namely Output Input, Location Quotient (LQ), and Miles and Huberman's Interactive Model Analysis which are described one by one as followed.

In general, the majority people of Tende Village work as field farmers with rice and vegetable production in Tende Village and some of them are in the neighboring village areas, namely Sambung Village, Randa Empas Village, and Tukuq Village. That four villages are located in one area which is on the border of East Kalimantan and Central Kalimantan, which belongs to the category 3T namely Underdeveloped, Outermost, and Leading.

\subsection{Location Quotient (LQ)}

Referring to the results of interviews with a number of informants and key informants, it can be obtained that the people of the Tende Village area that includes Sambung Village, Tende Village, Randa Empas Village, and Tukuq Village have a potential regional with 9 (nine) economic sectors, there are:

a. Processing industry sector. The processing industry is one of the sector that works in the industrial that makes a finished and non-finished goods to be marketable.

b. Transportation and communication sector. The transportation and communication sector can also be called the transportation sector.

c. Agro and marine sector. The agro and marine sector covers many sectors such as the agriculture sub-sector, fisheries sub-sector, plantation sub-sector, and livestock sub-sector.

d. Mining and excavation sector. This sector includes mining and excavation activities that produce the petroleum, natural gas, coal, gold, precious stones and etc.

e. Other natural wealth sectors. This sector includes the groundwater sub-sector, the electricity sub-sector, and others.

f. Property sector. The property sector consists of several sub-sectors such as the building or construction sub-sector, land ownership sub-sector, etc.

g. Tourism sector. The tourism sector consists of hotels, restaurants and management of other tourism places.

h. Sector of banks and other financial institutions. Management of banks and other financial institutions such as lending, rental and others.

i. Services sector. This sector includes various services produced by 8 other sectors.

In the analysis of this study, the LQ analysis obtained the economic sector data, there are in table 1. 
Table 1. Economic Sectors

\begin{tabular}{|c|c|c|c|c|c|}
\hline No & Sector & $\begin{array}{c}\text { Ti } \\
\text { (Tende } \\
\text { Regional } \\
\text { Workforce) }\end{array}$ & $\begin{array}{c}\text { Tt } \\
\text { (Bentian } \\
\text { Besar } \\
\text { Regional } \\
\text { Workforce) }\end{array}$ & $\begin{array}{c}\text { Li } \\
\text { (Tende } \\
\text { Regional } \\
\text { Employment } \\
\text { Field) }\end{array}$ & $\begin{array}{c}\text { Lt } \\
\text { (Bentian } \\
\text { Besar } \\
\text { Regional } \\
\text { Employment } \\
\text { Field) }\end{array}$ \\
\hline 1 & Processing industry & 8 & 130 & 15 & 131 \\
\hline 2 & $\begin{array}{l}\text { Transportation and } \\
\text { communication }\end{array}$ & - & - & - & - \\
\hline 3 & Agro & 650 & 3.425 & 5 & 111.632 \\
\hline 4 & Mining and excavation & - & - & - & - \\
\hline 5 & $\begin{array}{l}\text { other natural wealth (ironwood } \\
\text { and honey, swallow livestock) }\end{array}$ & 25 & 255 & 75 & 501 \\
\hline 6 & Property & - & - & - & - \\
\hline 7 & Tourism & - & - & - & - \\
\hline 8 & Bank and financial institutions & - & - & - & - \\
\hline 9 & Services & - & - & - & - \\
\hline
\end{tabular}

The formula used to calculate the Labor LQ Towards the Processing Industry Sector is obtained (table 1)

Indicator/Decision Making

LQ> 1 shows that there is a relative concentration in one region compared to the whole region. It means that there is a concentration (i) in an area which is a base sector which means that commodities in the region have a comparative advantage.

$\mathrm{LQ}=2$ is a non-base sector, meaning that the labors (i) in an area does not have a comparative advantage. Producing labor is only enough to meet one's own needs in the region.

LQ $<1$ is a non-base sector, meaning that labor (i) in an area does not have a comparative advantage, labor (i) in the region cannot meet its own needs and must obtain supplies from outside the region.

Thus based on the results of the above calculation it is known that $L Q<1$. This shows that the applicable LQ is LQ $<1$ which indicates the non-base sector, meaning that the labor (i) in the Tende region does not have a comparative advantage in the Processing Industry Sector, the labor (i) in the Tende region cannot meet its own needs and must get supplies from outside the region.

The formula used to calculate Labor LQ Towards the Agro Sector that obtained (table 1), thus based on the results of the above calculations it is known that $L Q=2$. This shows that the applicable LQ is LQ> 1 which shows there is a relative concentration in an area compared to the whole region. This means that concentration (i) in an area is a base sector, which means that the labor sector in the region has a comparative advantage. Excellent in agriculture, mountain rice, duck farming, goat breeding.

The formula used to calculate Labor LQ Against the Processing Industry Sector that obtained (table 1), thus based on the results of the above calculations it is known that LQ $<1$. This shows that the applicable LQ is LQ $<1$ which indicates other natural wealth sectors such as ironwood, natural honey, incidental swallow livestock which are non-base sectors, meaning 
that the labor (i) in the Tende region does not have comparative advantage, the labor (i) in the Tende region cannot meet their own needs and must obtain supplies from outside the region.

\subsection{Interactive Model Analysis}

Referring to the results of interviews with a number of key informants, it was obtained that the people of the Tende Village area which are included Sambung Village, Tende Village, Randa Empas Village, and Tukuq Village had the potential to be developed according to community empowerment needs including:

a. Farming skills. Generally, the people of Tende Village are farmers with agricultural products in the form of rice, cassava, and other several types of vegetables for daily food.

b. Rattan Crafting Skills. This skill is a hereditary inheritance from the ancestors of the Dayak tribe, especially the Bentian Dayak tribe. But based on the observations of the research team, the processed products of their rattan wicker crafts are not much different and can even be said to be the same as the rattan wicker crafts of other Dayak tribes in the Kalimantan region. The only thing that special from Tende Village is the canvas painting or woven "honey tree" wall motif that must be encouraged as a characteristic of Tende Village.

c. Human Resources. The phenomenon that occurs in Tende Village is that children who go to junior and senior high school prefer to study in the subdistrict capital namely Dilang Puti Village which is $+40 \mathrm{~km}$ away or with a travel time of $1.5-2$ hours compared to choosing to go to the neighbors village, namely SMP 1 in the Sambung Village with a distance of + $2 \mathrm{~km}$ or to SMPN 2 in Randa Empas Village which is $+1 \mathrm{~km}$ away, and there are even children who continue their junior and senior high school education to the capital of West Kutai Regency and to the Capital City East Kalimantan Province in Samarinda City. So that after graduating from school, the young generation of Tende Village chose to work outside the Tende Village.

d. Dayak Bentian Culture. As with other Dayak cultures, especially in East Kalimantan, the people of Tende Village have a number of cultures such as dances, traditional ceremonies, carvings, and other cultures, which can be continued by elementary school children who still live with their families in Tende Village.

The results of observations and interviews showed that the Tende Village area which included Sambung Village, Tende Village, Randa Empat Village, and Tukuq Village had a number of potentials that could be utilized to improve the economic conditions of the people in the border villages, which included:

a. Agriculture: Mountain Rice and Vegetables. It is the potential that can become an agricultural or agro power in the border region so that they can be self-sufficient in food, especially rice and vegetables. It can even be sold to rural areas of the Central Kalimantan border because it is only 30 minutes away.

b. Forest: ironwood, natural honey, rattan, other wood. Especially for rattan which is a commodity raw material for the production of community rattan woven crafts, while the use of ironwood trees, natural honey, and other wood is incidental which is only used for daily needs or partly sold, but not as the main needs of the community's economy such as rattan.

c. Education: Elementary School, SMPN 2 Bentian Besar is an asset that was built with large funds from the central government using the APBN with the intention that the junior secondary school age does not need to go to the District Capital or to other regions, because 
the junior secondary level is still very much needed protection of parents, families, and the people, until now the school that built in this 3T area has only 4 teachers and 6 students. This school can also be developed as a basis for developing culture for students.

d. Industry: Rattan Craft, Artificial Swallow Bird Nest. This sector is the main economic sector of the current Tende Village community, in addition to the agricultural sector of mountain rice and vegetables. However, the management, processing and marketing assistance is still needed in order to have higher additional value.

e. Tourism: Rattan Craft Workshop, Bentian Besar Culture (traditional hall, tradition and dance). It needs an extra energy to develop and sell rattan crafts and Dayak Bentian culture in the Tende Village area, especially considering the position of the Tende Village region which is in the $3 \mathrm{~T}$ category even though it is in the trans Kalimantan route. However, it is not impossible, if the people succeeds in finding the concept of tourism magnets based on the tourism study.

f. Health: border health center. As with the border tourism development sector, the health sector as a border health center still needs a deeper study and development, but it is not impossible to implement it.

Basically there are so many models for developing the potential of people and rural areas that are considered appropriate for the welfare of the people of a village. But as with the concept of the Republic of Indonesia National Development Planning Agency in Chapter 2 point 2.5 on a macro basis, the area of Tende Village that allows to apply are (1) models that are ecological research and tourism stations and (2) agropolitan area models.

For mezzo and micro applications, the two models must still be tested through studies and research in accordance with the characteristics and local wisdom of Tende Village. So that community empowerment and the potential of the region can be developed to achieve community welfare while still paying attention to environmental sustainability as the main carrying capacity for sustainable development.

\section{Conclusion}

The potential of the Tende Village community are in the form of farming skills in the fields, having the future human resources, and also Dayak Bentian culture. The potential of Tende Village covers the Agriculture sector, other natural resources such as forests that produce ironwood, natural honey, rattan, other wood, education sector, rattan handicraft sector, artificial swallow nest, tourism sector in the form of Bentian Besar Rattan and Culture workshop, and also health sector as a border health center. The potential development model of the community and the Tende Village area makes it possible to apply (1) models with ecological tourism and research stations and (2) agropolitan area models according to the characteristics and local wisdom of Tende Village.

\section{References}

[1] A. Gaudard, A. Wüest, and M. Schmid, "Using lakes and rivers for extraction and disposal of heat: Estimate of regional potentials," Renew. Energy, pp. 330-342, 2019. 
[2] W. Astuti, A. S. Permana, Qomarun, A. Febela, and R. Andisetyana, "Integrated planning model of creative industry based Kampung tourism in Jayengan Surakarta, Indonesia," Plan. Malaysia, vol. 15, no. 3, pp. 63-76, 2017.

[3] M. Alston and W. Bowles, Research for Social Workers. Canberra: Allen\& Unwin, 2003.

[4] A. P. Tjilen, Fitriani, H. Tambayong, A. Y. Maturan, S. W. Ririhena, and F. Y. Manuhutu, "Participation in empowering women and the potential of the local community economy, a case study in Merauke Regency, Papua Province," Int. J. Mech. Eng. Technol., vol. 9, no. 167-176, pp. 167-176, 2018.

[5] C. Pekdemir, "On the regulatory potential of regional organic standards: Towards harmonization, equivalence, and trade?," Glob. Environ. Chang., vol. 50, pp. 289-302, 2018.

[6] M. Kircher, R. Breves, A. Taden, and D. Herzberg, "How to capture the bioeconomy's industrial and regional potential through professional cluster management," $N$. Biotechnol., vol. 40, pp. 119-128, 2018.

[7] E. W. Gabisa and S. H. Gheewala, "Potential, environmental, and socio-economic assessment of biogas production in Ethiopia: The case of Amhara regional state," Biomass and Bioenergy, vol. 122, pp. 446-456, 2019.

[8] B. Kuch and E. Westkämper, "On the Evolution of Regional Efficiency Potentials," Procedia Manuf., vol. 11, pp. 1528-1535, 2017.

[9] A. Imran and K. Nikolai, "The assessment of regional economic potential based on the methodology of fuzzy set theory," Procedia Comput. Sci., vol. 120, pp. 372-375, 2017.

[10] A. M. Shikhalev, M. V Panasyuk, and I. A. Ahmetova, "Modelling of Conceptual Space of the 'Regional Social Potential' Term on the Basis of Fuzzy Frames," Procedia Econ. Financ., vol. 24, pp. 634-642, 2015.

[11] S. W. Vanderstoep and D. D. Johnston, Research Methods for Everyday Life. San Fransisco: Wiley \& Sons, 2009.

[12] N. Walliman, Research methods: The basics. Routledge, 2017.

[13] Y. S. L. Norman K. Denzin, handbook of qualitative research. Fourth edition. Thousand Oaks : SAGE, [2011] C2011, 2011. 